\title{
Development and Stability Evaluation of In- House Prepared External Quality Controls for Autoimmune Disease Tests
}

\author{
Soyoung Shin ${ }^{1 \oplus}$ and Joonhong Park ${ }^{2,3}$ \\ 1Department of Laboratory Medicine, College of Medicine, The Catholic University of Korea, Seoul; 2Department of Laboratory \\ Medicine, Jeonbuk National University Medical School; ${ }^{3}$ Research Institute of Clinical Medicine of Jeonbuk National University- \\ Biomedical Research Institute of Jeonbuk National University Hospital, Jeonju, Korea
}

\section{Corresponding author:}

Joonhong Park

Department of Laboratory Medicine, Jeonbuk National University Hospital, Jeonbuk National University Medical School, 20 Geonji-ro, Deokjin-gu, Jeonju 54907, Korea

Tel +82-63-250-1218

E-mail miziro@jbnu.ac.kr

Received: January 7, 2021 Revised: February 2, 2021 Accepted: February 8, 2021
This is an Open Access article distributed under the terms of the Creative Commons Attribution Non-Commercial License (http://creativecommons.org/licenses/ by-nc/4.0) which permits unrestricted non-commercial use, distribution, and reproduction in any medium, provided the original work is properly cited.
Background: The control samples for external quality assessment (EQA) must be highly stable during the EQA process. This study aimed to evaluate the stability of in-house prepared external quality controls for autoimmune disease tests, including anti-nuclear antibody (ANA), anti-double stranded DNA immunoglobulin G antibody (anti-dsDNA), anti-thyroglobulin antibody (anti-Tg), and anti-thyroperoxidase antibody (anti-TPO).

Methods: The in-house prepared external quality controls with two different levels (negative and positive for ANA and anti-dsDNA; low and high for antiTg; and anti-TPO) for each autoimmune disease test were prepared and stored at test temperatures of $-20^{\circ} \mathrm{C}, 4^{\circ} \mathrm{C}$, and room temperature (RT). The levels of each autoimmune disease test were measured at baseline and at 1 week, 2 weeks, 1 month, 3 months, and 6 months. The internal quality controls from the same batch run were also tested during the evaluation period.

Results: The negative and positive controls for ANA were stable for 6 months, regardless of storage temperature. The positive control for anti-dsDNA tended to increase in level at 6 months $(P=0.033)$. The low and high anti-Tg controls tended to decrease in levels at 3 months ( $P=0.033$ and $P=0.042$, respectively). The low control of anti-TPO decreased in level at RT compared to $-20^{\circ} \mathrm{C}$ at 1 week $(P=0.026)$ and the high anti-TPO controls tended to decrease in level at 3 months regardless of storage temperature such as $-20^{\circ} \mathrm{C}, 4^{\circ} \mathrm{C}$, and RT $(P=0.041)$.

Conclusions: The stability of in-house prepared external quality controls was influenced by different storage temperatures and durations. These results indicate that all EQA samples for autoimmune disease tests should be stored at $-20^{\circ} \mathrm{C}$ or $4^{\circ} \mathrm{C}$ and be tested as soon as possible during the EQA process.

(Lab Med Qual Assur 2021;43:72-79)

Key Words Stability evaluation, In-house prepared quality controls, External quality assessment, Autoimmune disease tests 
서론

자가면역질환(autoimmune disease)은 우리 몸의 면역계가 자기관용성(self-tolerance)에 이상이 발생하여 체내의 자기조직 을 파괴하고, 그 결과 신체 내외에 증상을 발현하는 질환이다[1]. 이러한 자가면역질환은 인체의 어떠한 조직도 파괴대상이 될 수 있기 때문에 근골격계, 신장계, 혈액계, 호흡기계, 내분비계, 소화 기계 등 다양한 기관에서 발생할 수 있다. 자가면역질환의 유병률 증가로 인하여 임상에서 이러한 질환들이 의심되거나 이미 이환되 어 있는 환자들을 진료하게 될 가능성이 높아졌다. 임상의사들이 진료과정에서 진단, 치료, 예후판정 및 진료상담의 의학적 근거를 제시하기 위해 자가면역질환 관련 체외진단검사에 대한 안정적이 고 정확한 정도관리가 임상검사실의 중요 업무로 요구된다[2]. 임 상검사실에서 검사의 정밀도를 관리하기 위하여 내부정도관리를 시행하고 있으나, 대부분 검사의 경우 기준 검사법으로 정확한 정 도관리 목표값을 사전에 측정한 상품화된 정도관리물질이 없거나 이러한 정도관리물질이 판매되어도 비용적인 부담으로 통상적인 내부정도관리에 사용되는 경우는 드물다. 따라서 대부분의 임상검 사실이 정확한 목표치가 정해져 있지 않고 보통 시약이나 장비회 사에서 제공하는 참고용 목표범위만 제시되어 있는 상품화된 정도 관리물질을 자체적으로 허용범위를 설정하여 내부정도관리용 물 질로 사용하고 있다. 이러한 상황에서 대부분 임상검사실의 일상 적인 내부정도관리활동은 주로 검사의 정밀도를 검증하기 위한 목 적으로 시행되고 있다. 따라서 검사의 정확도에 대한 평가를 위해 서는 다기관이 참여하는 외부정도관리에 참가하여 검사의 정확도 를 평가받는 것이 필수적이다[3]. 한편, 외부정도관리를 위해서는 다량, 동질의 정도관리물질이 안정적으로 참여기관에 배포되어야 한다[4]. 보통 기질효과의 최소화 및 제조과정의 편의를 위하여 자 가제조 혈청이나 혈장을 대량으로 제조하여 분주한 후 외부정도관 리에 참여하는 검사실에 배포하게 되는데, 이 과정에서 정도관리 물질이 변질될 가능성이 있다. 또한 상품화된 정도관리물질이 없 는 일부 검사의 경우 검사실 내부정도관리를 위하여 자가제조 혈 청을 사용하기도 한다. 따라서 정확한 외부정도관리 프로그램을 운영하기 위하여 보관온도 및 보관기간에 따른 정도관리물질의 안 정성 평가가 선행될 필요가 있다[5].

본 연구에서는 자가면역성 류마티스질환의 체외진단검사로 널리 이용되는 anti-nuclear antibody (ANA), anti-double stranded DNA immunoglobulin G (IgG) antibody (anti$\mathrm{dsDNA}$ )와 자가면역성 갑상선질환의 체외진단검사로 이용되는 anti-thyroglobulin antibody (anti- $\mathrm{Tg}$ ), anti-thyroperoxidase antibody (anti-TPO)를 대상으로 외부정도관리를 위한 자가제 조 혈청을 각각 제조하여 보관온도 및 기간에 따라 농도를 반복
측정하여 자가제조 외부정도관리물질의 안정성을 평가하고자 하 였다.

\section{재료 및 방법}

\section{1. 대상}

2018년 7월에서 9월 동안 대전성모병원 진단검사의학과 진단 면역 부서에서 ANA 형광현미경 정성검사, anti-dsDNA 정성검 사, anti-Tg와 anti-TPO 정량검사가 의뢰된 환자의 검사결과를 확인하여 검사결과 통보 후 잔여 검체를 수집하였다. 각 자가면 역질환 검사항목의 결과가 ANA 형광현미경 정성검사는 음성, 양 성(homogenous와 speckled pattern), anti-dsDNA 정성검사 는 음성 $(<10 \mathrm{IU} / \mathrm{mL})$, 양성 $(>30 \mathrm{IU} / \mathrm{mL})$, anti-Tg 정량검사는 참 고치 이내(<115 IU/mL), 참고치 상한보다 5-10배 이상 고농도, anti-TPO 정량검사는 참고치 이내 $(<34 \mathrm{IU} / \mathrm{mL})$, 참고치 상한보다 5-10배 이상 고농도인 혈청을 각각 수집하여 자가제조 혈청을 제 조하기 전까지 파라핀 필름으로 밀봉하여 냉장보관하였다. 수집 된 혈청은 자가면역질환 검사항목의 종류 및 농도별로 혼주한 후 마그네틱 바와 교반기를 사용하여 $150 \mathrm{rpm}$ 으로 18시간 동안 냉 장상태에서 섞어서 균질화한 후 Corning Bottle-Top Vacuum Filter, $0.22 \mu \mathrm{m}$ Pore (Corning Life Sciences, Tewksbury, MA, USA)를 이용하여 섬유소를 제거하였다. 4 가지 자가면역질환 검사항목에 대해 각각 음성과 양성, 저농도(정상 참고치 내외)와 고농도(정상 참고치 상한의 5-10배)의 자가제조 혈청을 $60 \mathrm{~mL}$ 이상의 양이 되도록 제조하였다. ANA 검사는 음성(역가 1:40 이 하)과 양성(homogenous와 speckled, 역가 1:80 이상)으로 제 조하였고, anti-dsDNA 검사는 음성 $(<10 \mathrm{IU} / \mathrm{mL})$ 과 양성(>60 IU/ $\mathrm{mL})$, anti-Tg와 anti-TPO 검사는 정상 참고치 상한 근처의 농도 와 참고치 상한의 5-10배 근처의 고농도 물질을 제조하였다. 각 자검체는 뚜껑이 있는 $1.2 \mathrm{~mL}$ 마이크로 튜브에 분주하였고, 증발 로 인한 농축을 방지하기 위하여 용기의 뚜껑을 닫은 후 파라핀 필 름으로 밀봉하였다.

\section{2. 방법}

제조 당일에 각각의 자가제조 혈청을 10 회 반복 측정한 평균을 기준값(baseline)으로 산출하였다. ANA, anti-dsDNA, anti-Tg, anti-TPO의 각각의 자가 제조혈청에 대해 자검체를 $500 \mu \mathrm{L}$ 씩 분 주하여 10 개씩 냉동 $\left(-20^{\circ} \mathrm{C}\right)$, 냉장 $\left(4^{\circ} \mathrm{C}\right)$ 및 실온 $\left(24^{\circ} \mathrm{C}\right)$ 에서 1 주, 2 주, 1 개월, 3 개월, 6 개월 보관하였다. 각 측정일에 보관조건별 자 검체 10 개를 연속으로 측정하였고 여분의 자검체는 재검 및 오 염 등에 대비해 보관되었다. 연구대상 기간에 각 자가면역질환 자 가제조 혈청 중 ANA 형광현미경 정성검사는 혈청을 phosphate 
buffered saline (PBS)으로 40배 희석한 후 HEp-2 세포가 고정 된 슬라이드(Bio-Rad Laboratories, Redmond, WA, USA)에 도 포하고 실온 암소에서 20 분간 반응시켰다. 슬라이드는 $\mathrm{PBS}$ 로 세 척 후 FITC (fluorescein isothiocyanate)-labeled conjugate 를 도포하여 실온 암소에서 20 분간 반응시키고 PBS로 다시 세 척 후 coverslip으로 덮어 형광현미경하에서 형광강도를 관찰하 였다. ANA 검사상 양성인 경우 희석배수를 추가하여 반정량 역가 검사를 시행하였으며, 항체 역가가 1:80 이상인 경우 양성, 1:40 의 경우는 약양성, $1: 40$ 미만의 경우 음성으로 판정하였다. Anti$\mathrm{dsDNA}$ 정성검사는 혈청에서 $\mathrm{dsDNA}$ 에 대한 $\lg \mathrm{g}$ 항체를 효소 면역결합흡수법(enzyme linked immunosorbent assay) 으로 정량하는 체외진단분석기용 시약 CHORUS dsDNA-G (DIESSE Diagnostica Senese Spa, Tuscany, Italy)를 이용 하여 측정하였다. 측정범위(analytic measurement range, $\mathrm{AMR})$ 는 1-150 IU $/ \mathrm{mL}$ 였고, 판정기준은 음성 $(<20 \mathrm{IU} / \mathrm{mL})$, equivocal (20-30 IU/mL), 양성 $(>30 \mathrm{IU} / \mathrm{mL})$ 으로 정성적으로 판정하였다. Anti-Tg과 anti-TPO 정량검사는 전기화학발광법 (electrochemiluminescence) 원리를 이용한 COBAS e602 면 역측정시스템(Roche Diagnostics, Mannheim, Germany) 및 동사의 전용 시약을 사용하여 측정하였다. AMR은 anti-Tg 104,000 IU/mL, anti-TPO 5-600 IU/mL였고 정상 참고치는 anti$\mathrm{Tg} 115 \mathrm{IU} / \mathrm{mL}$ 이하, anti-TPO $34 \mathrm{IU} / \mathrm{mL}$ 이하였다. 검사실에서 자체 설정한 내부정도관리 목표값과 허용범위를 적용한 내부정도 관리를 만족한 경우에만 검사결과를 수집하였다. 모든 검사과정은 각 제조사의 지침에 따랐으며, 통상적인 외부정도관리와 마찬가지 로 본 연구에서 제조된 자가제조 외부정도관리물질을 환자 검체와 동일하게 취급하여 검사 당일 아침에 각 자가면역질환 검사당 두 가지 농도의 정도관리물질을 사용하여 내부정도관리를 시행한 후 정규검사시간 중에 환자 검체와 함께 제조된 외부정도관리물질을 검사하였다. 연구기간에 동일 생산번호(lot number)의 검사시약 과 내부정도관리물질을 사용하여 각 자가면역질환검사에서 기질 효과와 계통오차 등의 영향을 최소화하였다.

\section{3. 통계분석}

연구기간 동안 보관온도와 보관기간에 따라 각 자가제조 외부 정도관리물질의 종류, 농도의 안정성 평가를 위하여 각 보관조건 별 10 회 반복 측정결과의 평균, 표준편차, 변이계수를 산출하였 다. Kruskal-Wallis 시험을 사용하여 자가제조 혈청을 제조한 기 준값과 각 보관조건에 따른 각 자가제조 외부정도관리물질의 측 정결과를 다중비교하였으며, 제1종 통계오류를 보정하기 위하여 Bonferroni 교정법을 적용하였다. 마찬가지로 같은 검사일에 측 정한 결과의 보관조건별 차이는 냉동보관 자가제조 혈청의 결과
를 기준으로 냉장 및 실온보관 자가제조 혈청의 측정결과와 다중 비교하여 분석하였다. 모든 통계분석에는 MedCalc Statistical Software ver. 17.6 (MedCalc software, Ostend, Belgium)을 사용하였고 P값이 0.05 이하인 경우 유의한 것으로 판정하였다.

\section{결과}

\section{1. 연구기간 중 내부정도관리 결과}

연구기간 동안 ANA, anti-dsDNA, anti-Tg 및 anti-TPO 4종 의 자가면역질환검사에 대한 내부정도관리를 각각 2 가지 농도의 정도관리물질로 시행하였다. 연구기간 동안 정도관리물질의 동일 생산번호를 유지하여 내부정도관리를 시행하였으므로 내부정도 관리 목표치 및 허용범위는 일정하게 유지되었다. 자가제조 혈청 의 안정성 평가를 시행하였던 ANA, anti-dsDNA 정성검사의 내부 정도관리는 연구기간에 음성과 양성 정도관리물질로 평가하여 모 두 판정기준이 일치하였다. Anti-Tg와 anti-TPO는 연구기간에 정 도관리물질 농도 측정결과의 변이계수는 anti-Tg의 경우 저농도 $5.8 \%$ (평균 $75.6 \mathrm{IU} / \mathrm{mL}$; 표준편차 $4.4 \mathrm{IU} / \mathrm{mL}$ ), 고농도 5.9\%(평 균 $161.6 \mathrm{IU} / \mathrm{mL}$; 표준편차 $9.5 \mathrm{IU} / \mathrm{mL}$ )였고, anti-TPO의 경 우 저농도 $7 \%($ 평균 $26.6 \mathrm{IU} / \mathrm{mL}$; 표준편차 $1.9 \mathrm{IU} / \mathrm{mL}$ ), 고농도 $2.1 \%$ (평균 $77.6 \mathrm{IU} / \mathrm{mL}$; 표준편차 $1.6 \mathrm{IU} / \mathrm{mL}$ )였다.

\section{2. 보관조건에 따른 자가제조 혈청의 안정성}

연구기간 동안 4종의 각 자가면역질환검사에 대하여 두 가지 농 도의 자가제조 혈청을 냉동, 냉장 및 실온상태에서 6 개월간 보관 하면서 제조 당일, 1 주, 2 주, 1 개월, 3 개월, 6 개월 시점에서 각각 10 개의 자검체를 연속 측정한 결과의 안정성 추이는 다음과 같았 다. ANA 정성검사는 음성, 양성(homogeneous과 speckled)에 대해 기준값에서 각각 음성(역가 1:40 이하), homogeneous 양 성(역가 1:160), speckled 양성(역가 1:320)이었으며 1주, 2주, 1 개월, 3 개월, 6 개월 후 냉동, 냉장, 실온에서 시행한 검사에서 모 두 역가의 변화가 없이 음성, homogeneous 양성, speckled 양 성이었다. 결과적으로 ANA 검사의 음성, 양성 형광양상은 모든 보 관조건에서 제조 당일의 역가가 6 개월 동안 유지되었다(Table 1). Anti-dsDNA 검사는 정량적으로 검사하나 정성결과로 통보되는 검사로, 음성 $(<10 \mathrm{IU} / \mathrm{mL})$ 물질은 1 주, 2 주, 1 개월, 3 개월, 6 개월 후 냉동, 냉장, 실온에서 시행한 검사에서 모두 음성으로 모든 보 관조건에서 음성이었다. Anti-dsDNA 양성 물질은 $30 \mathrm{IU} / \mathrm{mL}$ 이 상인 경우로 제조 당일 기준값은 $80.9 \mathrm{IU} / \mathrm{mL}$ 였고 표준편차 2.3 $\mathrm{IU} / \mathrm{mL}$, 변이계수 $2.8 \%$ 였다. Anti-dsDNA 양성 물질의 경우 모 든 보관조건에서 양성이었으나 보관기간 동안 냉동(6 months, $114.1 \mathrm{IU} / \mathrm{mL})$, 냉장 $(6$ months, $105 \mathrm{IU} / \mathrm{mL})$, 실온 6 months, 
Table 1. Changes in the levels of ANA by indirect immunofluorescence assay in the pooled sera according to the storage condition and duration

\begin{tabular}{|c|c|c|c|c|c|c|c|}
\hline ANA & $\begin{array}{l}\text { Storage } \\
\text { condition }\end{array}$ & Baseline & 1 week & 2 weeks & 1 month & 3 months & 6 months \\
\hline \multirow[t]{3}{*}{ Negative } & $-20^{\circ} \mathrm{C}$ & $<1: 40$ & $<1: 40$ & $<1: 40$ & $<1: 40$ & $<1: 40$ & $<1: 40$ \\
\hline & $4^{\circ} \mathrm{C}$ & $<1: 40$ & $<1: 40$ & $<1: 40$ & $<1: 40$ & $<1: 40$ & $<1: 40$ \\
\hline & $\mathrm{RT}$ & $<1: 40$ & $<1: 40$ & $<1: 40$ & $<1: 40$ & $<1: 40$ & $<1: 40$ \\
\hline \multirow[t]{3}{*}{ Homogeneous } & $-20^{\circ} \mathrm{C}$ & $1: 160$ & $1: 160$ & $1: 160$ & $1: 160$ & $1: 160$ & $1: 160$ \\
\hline & $4^{\circ} \mathrm{C}$ & $1: 160$ & $1: 160$ & $1: 160$ & $1: 160$ & $1: 160$ & $1: 160$ \\
\hline & $\mathrm{RT}$ & $1: 160$ & $1: 160$ & $1: 160$ & $1: 160$ & $1: 160$ & $1: 160$ \\
\hline \multirow[t]{3}{*}{ Speckled } & $-20^{\circ} \mathrm{C}$ & $1: 320$ & $1: 320$ & $1: 320$ & $1: 320$ & $1: 320$ & $1: 320$ \\
\hline & $4^{\circ} \mathrm{C}$ & $1: 320$ & $1: 320$ & $1: 320$ & $1: 320$ & $1: 320$ & $1: 320$ \\
\hline & $\mathrm{RT}$ & $1: 320$ & $1: 320$ & $1: 320$ & $1: 320$ & $1: 320$ & $1: 320$ \\
\hline
\end{tabular}

Abbreviations: ANA, anti-nuclear antibody; RT, room temperature $\left(20^{\circ} \mathrm{C}-24^{\circ} \mathrm{C}\right)$.

$96.4 \mathrm{IU} / \mathrm{mL}$ )에서 검사결과의 정량값이 증가하는 양상을 보였다. Anti-Tg 검사는 정량적으로 검사하고 정량결과로 통보되는 검사 로 저농도 물질은 정상 상한치 $(115 \mathrm{IU} / \mathrm{mL})$ 근처의 농도인 126.4 $\mathrm{IU} / \mathrm{mL}$ 로 제조하였고 표준편차 $6.1 \mathrm{IU} / \mathrm{mL}$, 변이계수 $4.8 \%$ 였다. 고농도 물질은 AMR 상한의 $50 \%$ 근처의 농도인 $2,366.4 \mathrm{IU} / \mathrm{mL}$ 로 제조하였고 표준편차 $146.7 \mathrm{IU} / \mathrm{mL}$, 변이계수 $6.2 \%$ 였다. 저농 도와 고농도 물질 모두 냉동 $(6$ months; 저농도 $61.6 \mathrm{IU} / \mathrm{mL}$, 고 농도 $2,090.6 \mathrm{IU} / \mathrm{mL}$ ), 냉장 $(6$ months; 저농도 $51.2 \mathrm{IU} / \mathrm{mL}$, 고 농도 $2,001.2 \mathrm{IU} / \mathrm{mL}$ ), 실온 $(6$ months; 저농도 $43.3 \mathrm{IU} / \mathrm{mL}$, 고 농도 $1,863.3 \mathrm{IU} / \mathrm{mL}$ )에서 보관기간 동안 검사결과가 대체로 감소 하는 양상을 보였다. Anti-TPO 검사는 정량적으로 검사하고 정량 결과로 통보되는 검사로, 저농도 물질은 정상 상한치 $(34 \mathrm{IU} / \mathrm{mL})$ 근처의 농도인 $36.8 \mathrm{IU} / \mathrm{mL}$ 로 제조하였고 표준편차 $2 \mathrm{IU} / \mathrm{mL}$, 변 이계수 5.3\%였다. 고농도 물질은 AMR 상한의 $70 \%$ 근처의 농도 인 $412.8 \mathrm{IU} / \mathrm{mL}$ 로 제조하였고 표준편차 $22.7 \mathrm{IU} / \mathrm{mL}$, 변이계수 $5.5 \%$ 였다. Anti-Tg 검사와 유사하게 저농도와 고농도 물질 모두 냉동(6 months; 저농도 $30.9 \mathrm{IU} / \mathrm{mL}$, 고농도 $357.9 \mathrm{IU} / \mathrm{mL}$ ), 냉 장 $(6 \mathrm{months}$; 저농도 $25.7 \mathrm{IU} / \mathrm{mL}$, 고농도 $342.7 \mathrm{IU} / \mathrm{mL})$, 실온 6 months; 저농도 $21.2 \mathrm{IU} / \mathrm{mL}$, 고농도 $328.2 \mathrm{IU} / \mathrm{mL}$ )에서 보관기 간 동안 검사결과가 대체로 감소하는 양상을 보였다(Table 2).

\section{3. 보관조건에 따른 자가제조 혈청의 농도 추이}

정량적 측정을 시행한 anti-dsDNA, anti-Tg 및 anti-TPO의 자 가면역질환검사에 대하여 저농도 및 고농도 자가제조 혈청을 제 조한 당일 10 회 측정한 기준값과 비교하여 냉동, 냉장 및 실온에 서 보관하면서 1 주, 2 주, 1 개월, 3 개월, 6 개월 시점에서 각각 10 개 의 자검체를 연속 측정한 보관온도 및 보관기간별 농도 변화를 도
식화하였다(Fig. 1). Anti-dsDNA의 경우 음성 물질은 측정기간 동 안 AMR 하한 미만으로 측정되었다. 양성 물질은 보관온도에 따 른 차이는 없었으나 $(P=0.521)$, 보관기간에 따른 차이가 관찰되었 다 $(P=0.037)$. 제조 당일 기준값과 1 주 후 농도가 증가하였고(냉동 $11.9 \%$, 냉장 $13 \%$, 실온 $10.9 \% ; P=0.033), 1$ 주에서 3 개월 동안 농도는 안정적이었으나 6 개월 측정 시에는 다시 농도가 증가하는 경향을 보였다(냉동 $41 \%$, 냉장 $29.8 \%$, 실온 $19.2 \% ; P=0.042$ ) (Fig. 1A, B). Anti-Tg의 경우 보관온도에 따른 차이는 없었으나(저 농도, $P=0.621$; 고농도, $P=0.675)$, 보관기간에 따른 차이가 관찰 되었다(저농도, $P=0.010 ;$ 고농도, $P=0.008$ ). 저농도 물질의 경우 기준값과 1 주 후 농도가 감소하였고(냉동 $-11.1 \%$, 냉장 $-11 \%$, 실온 $-18 \% ; P=0.045), 1$ 주에서 1 개월 동안 농도는 대체로 안정 적이었으나 3개월(냉동 $-35.8 \%$, 냉장 $-47 \%$, 실온 $-62.4 \%$ )과 6 개월(냉동 $-51.3 \%$, 냉장 $-59.5 \%$, 실온 $-65.7 \%$ ) 측정 시에는 다 시 농도가 감소하는 경향을 보였다 $(P=0.033)$. 고농도 물질의 경우 기준값과 2주 후 농도가 유의하게 감소하였고(냉동 $-3.8 \%$, 냉장 $-5.2 \%$, 실온 $-5.9 \% ; P=0.037), 2$ 주에서 3 개월 동안 농도는 대체 로 안정적이었으나 6 개월 측정 시에는 다시 농도가 감소하는 경향 을 보였다(냉동 $-11.7 \%$, 냉장 $-15.4 \%$, 실온 $-21.3 \% ; P=0.042$ ) (Fig. 1C, D). Anti-TPO의 경우 저농도 물질에서 실온보관인 경우 냉동과 냉장보관보다 농도 감소가 6 개월 후 유의하게 관찰되었으 나(냉동 $-16 \%$, 냉장 $-30.2 \%$, 실온 $-42.4 \% ; P=0.026$ ), 보관기간 에 따른 차이는 없었다 $(P=0.161)$. 고농도 물질에서 보관온도에 따 른 차이는 없었으나 $(P=0.341)$, 기준값과 1 주 후 농도가 감소하였 고(냉동 $-6.6 \%$, 냉장 $-8.2 \%$, 실온 $-9.2 \% ; P=0.046), 1$ 주에서 1 개월 동안 농도는 대체로 안정적이었으나 3 개월(냉동 $-12.2 \%$, 냉 장 $-13.4 \%$, 실온 $-16.2 \% ; P=0.041$ )과 6 개월(냉동 $-13.3 \%$, 냉장 


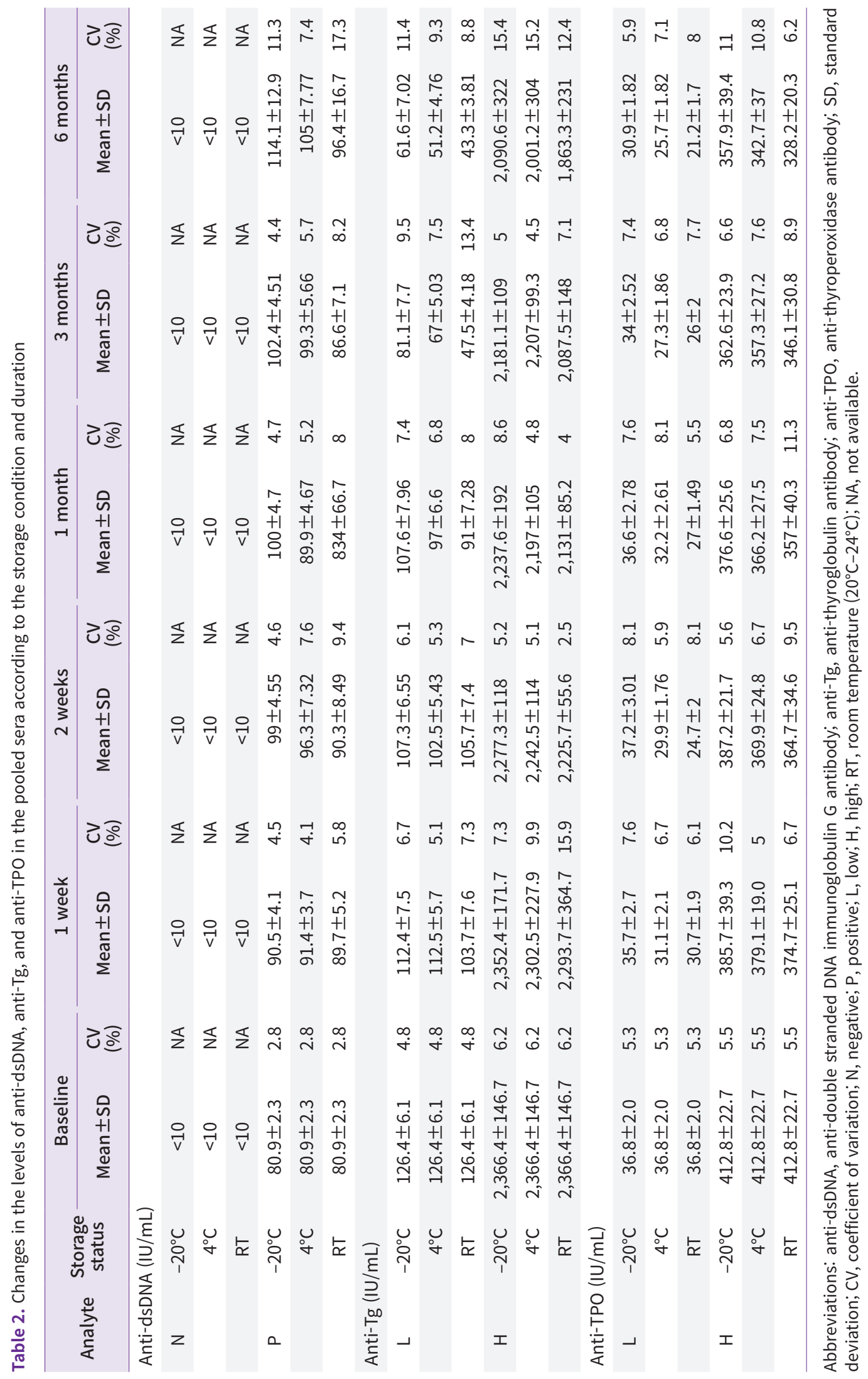



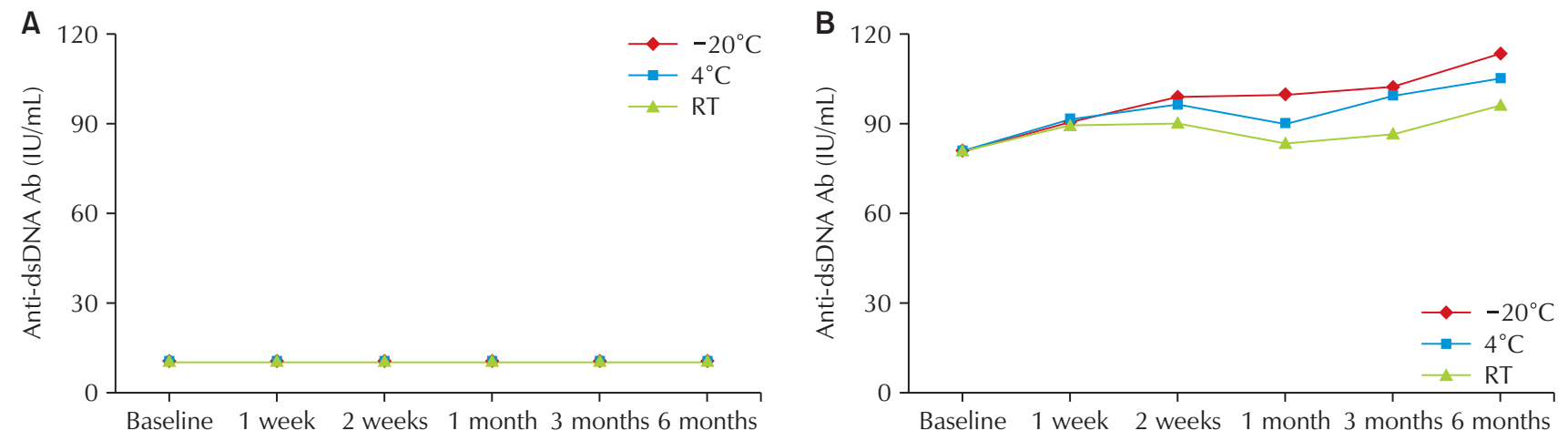

Time
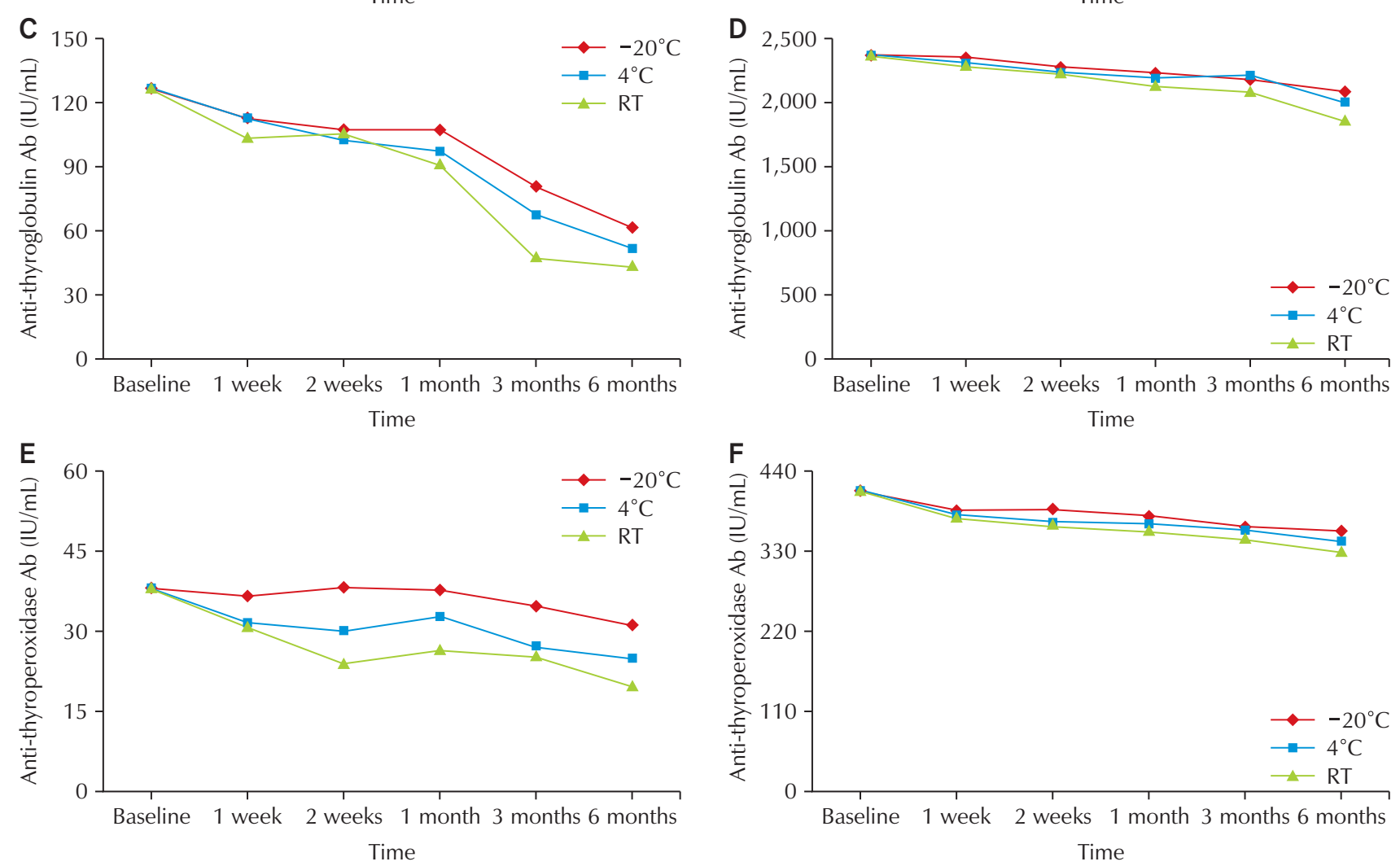

Fig. 1. The changes of level of in-house prepared external quality controls for autoimmune disease tests during a 6 month time period. Abbreviations: anti-dsDNA, anti-double stranded DNA immunoglobulin G antibody; anti-Tg, anti-thyroglobulin antibody; anti-TPO, antithyroperoxidase antibody; RT, room temperature $\left(20^{\circ} \mathrm{C}-24^{\circ} \mathrm{C}\right)$.

$-17 \%$, 실온 $-20.5 \%)$ 측정 시에는 다시 농도가 감소하는 경향을 보였다(Fig. 1E, F).

\section{고찰}

자가면역질환검사는 자가면역질환의 진단, 치료, 예후평가에 널리 사용되고 있어 검사의 정밀도뿐만 아니라 정확도의 신뢰성 을 유지하는 것이 임상적으로 매우 중요하다[6]. 그러나 대부분의
자가면역질환검사의 경우 검사시약마다 검출대상이 되는 항체 부 위에 차이가 있으므로 사용되는 장비와 시약 간에 차이가 있을 수 있다 $[7,8]$. 각 임상검사실에서 사용하는 자가면역질환검사는 기준 검사법으로 측정한 결과로 검증된 표준물질을 사용하여 정도관리 를 시행하지 않는 경우, 통상적인 정도관리물질을 사용하는 내부 정도관리만으로 검사의 정확도를 관리하기 어려울 수 있다. 따라 서 검사의 정확도를 보증하기 위해서 외부정도관리 프로그램에 참 가하여 검사실 측정결과를 동일한 검사원리, 검사장비, 검사시약 
으로 시행하는 다른 검사실들과의 결과를 비교하는 것이 추천된 다. 이때 보관조건의 영향을 최소화하여 배포되는 외부정도관리물 질의 안정성은 정확한 외부정도관리 프로그램 운영을 위한 전제조 건으로 요구된다. 본 연구에서는 검사 후 잔여 검체를 이용하여 자 가제조 혈청을 제조하고 기질효과의 영향을 줄일 수 있도록 18 시 간 이상 충분히 냉장상태에서 교반하여 외부정도관리용 물질의 보 관조건 및 기간에 따른 안정성을 평가하였다. 자가면역질환검사의 민감도와 특이도, 질환활성도 평가는 각 자가면역질환검사의 농도 에 따라 달라지므로 매우 높거나 낮은 자가면역질환검사 농도보다 는 정상 참고치 또는 양성/음성 판정기준 근처의 농도에 대한 검사 의 정밀도 및 물질 안정성이 검사의학적으로 더 중요하다. 따라서 저농도 물질은 각 자가면역질환검사의 정상참고치 상한, 양성/음 성 판정기준 내외 농도가 되도록 제조하였다. 고농도 물질은 각 자 가면역질환검사의 AMR 상한의 $50 \%-70 \%$ 이내의 물질을 제조하 여 평가하였다. 제조된 자가제조 혈청의 안정성 평가를 위하여 반 복 측정한 결과가 검사실 및 검사법 자체의 무작위 오류 또는 정밀 도 및 계통오차에 영향을 받을 수 있기 때문에 제조된 자가제조 혈 청의 안정성뿐 아니라 대상기간 동안 해당 검사의 내부정도관리 결과도 참고하였다.

본 연구결과에 의하면 자가면역질환검사에 대한 외부정도관리 용 자가제조혈청 중 ANA 물질은 보관온도와 상관없이 6개월까 지 평가결과가 안정적이었다. 그러나 anti-dsDNA, anti-Tg, antiTPO 물질은 시간이 지나면서 검사결과가 증가하거나 감소하는 경향을 보였다. Anti-dsDNA 고농도 물질의 경우 6개월 동안 농 도가 증가하는 경향을 보였으나 1 주에서 3 달 동안은 안정하였다. Anti-Tg 물질의 경우 6 개월 동안 농도가 감소하는 경향을 보였으 나 저농도 물질의 경우 1 주에서 1 개월 동안은 안정하였고 고농도 물질의 경우 2주에서 3개월 동안 안정하였다. Anti-TPO의 경우 6 개월 동안 농도가 감소하는 경향을 보였으나 저농도 물질의 경우 보관온도의 영향을 받았고 6 개월 동안 통계적으로 유의한 차이는 없었고 고농도 물질의 경우 1 주에서 1 개월 동안 안정하였다. 정량 적 측정이 가능한 anti-dsDNA, anti-Tg, anti-TPO 물질의 경우 1 주 또는 2주차에 농도변화가 관찰되었는데, 이는 검사항목의 농도 변화보다는 검사의 무작위 오류 및 계통오차에 의한 것으로 생각 된다. 그러나 1 개월, 3 개월, 6 개월 측정시점에서의 농도변화는 보 관온도 또는 보관기간에 영향을 받는 것으로 생각할 수 있다. 본
연구의 제한점은 단일 혈청과의 안정성 비교를 시행하지 않아 다 수의 검체의 혼주함으로써 발생할 수 있는 기질효과를 평가하지 못했고, 해당 검사항목만의 검사 후 잔여 검체를 이용함으로써 자 가제조 혈청의 안정성에 영향을 미칠 수 있는 다른 검사항목의 존 재를 확인하지 않아 각 자가제조 혈청의 불안정성 원인을 정확하 게 규명하지 못하였다. 공여 혈청을 이용하여 혼주혈청을 제조할 경우 고려할 수 있는 주요 가정은 하나 또는 소수 공여 혈청에 의 해 제조된 혼주혈청이 부정적인 영향을 받지 않는다는 것이다. 따 라서 가능하면 의도한 측정값을 제조하는데 영향을 미치는 것으로 알려진 공여 혈청을 배제하는 것이 중요하다[9]. 보통 외부정도관 리 참여기관에서 정도관리물질을 수령한 후 수일 내에 검사를 시 행하므로 자가제조 혈청의 보관온도와 기간에 따른 안정성이 외부 정도관리 결과에 유의한 영향을 끼치지는 않을 것으로 기대되나, 방부 처리하지 않고 단순히 환자 혈청을 혼주한 후 여과한 자가제 조 혈청을 배포할 경우 빠른 시일 내에 검사를 시행하는 안내문을 배포하는 것이 고려된다.

결론적으로 외부정도관리에 참여하는 기관은 되도록이면 물질 을 전달받은 후 냉장 또는 냉동보관한 후 빠른 시일 안에 검사하는 것을 추천하고 검사시행이 지연되는 경우에는 냉동 또는 냉장보관 하는 것이 고려된다. 자가면역질환검사에 대한 외부정도관리용으 로 검사 후 잔여 검체를 이용하여 자가제조 혈청을 제조하여 참여 기관에 정도관리용 자가제조 혈청을 동시에 배포하면 검사 전 요 소에 의한 영향을 적게 받아 외부정도관리 결과에 통계적으로 유 의한 영향을 미치지 않을 것으로 판단되므로 자가제조 혈청을 사 용하여 외부정도관리를 시행하는 것이 자가면역질환검사의 정확 도 검증에 기여할 것으로 판단된다.

\section{감사의 글}

이 연구는 대한임상검사정도관리협회의 2018년도 학술연구과 제 연구비(과제번호: 2018-12) 지원으로 수행되었다.

\section{ORCID}

Soyoung Shin https://orcid.org/0000-0002-8422-441X Joonhong Park https://orcid.org/0000-0001-7354-4234

\section{REFERENCES}

1. Kim J, Choe J. Introduction to autoimmune disease. J Korean Med Assoc 2009;52:638-44.

2. Bizzaro N, Bossuyt X, Haapala AM, Shoenfeld Y, Sack U. Accreditation in autoimmune diagnostic laboratories: a position paper of the European Autoimmunity Standardisation Initiative (EASI). Autoimmun Rev 2017;16:81-6. 
3. Pham BN, Albarede S, Guyard A, Burg E, Maisonneuve P. Impact of external quality assessment on antinuclear antibody detection performance. Lupus 2005;14:113-9.

4. Van Blerk M, Bossuyt X, Humbel R, Mewis A, Servais G, Tomasi JP, et al. Belgian recommendations on ANA, antidsDNA and anti-ENA antibody testing. Acta Clin Belg 2014;69:83-6.

5. Henriksen GM, Pedersen MM, Norgaard I, Blom M, Blou L, Blaabjerg O, et al. Minimally processed fresh frozen human reference sera: preparation, testing, and application to international external quality assurance. Scand J Clin Lab Invest 2004;64:293-308.

6. Mahler M, Dervieux T. Comments on recent advances and recommendations for the assessment of autoantibodies to cellular antigens referred as antinuclear antibodies. Ann Rheum Dis 2014;73:e36.

7. Hanly JG, Su L, Farewell V, Fritzler MJ. Comparison between multiplex assays for autoantibody detection in systemic lupus erythematosus. J Immunol Methods 2010;358:75-80.

8. Kim Y, Park Y, Lee EY, Kim HS. Comparison of automated multiplexed bead-based ANA screening assay with ELISA for detecting five common anti-extractable nuclear antigens and anti-dsDNA in systemic rheumatic diseases. Clin Chim Acta 2012;413:308-11.

9. Danilenko U, Vesper HW, Myers GL, Clapshaw PA, Camara JE, Miller WG. An updated protocol based on CLSI document C37 for preparation of off-the-clot serum from individual units for use alone or to prepare commutable pooled serum reference materials. Clin Chem Lab Med 2020;58:368-74. 